\title{
Assessment of the University Vision, Goals, Mission and Program Objectives: A Management Protocol for Quality Assurance
}

\author{
By Bretel B. Dolipas ${ }^{*}$, Julie A. Buasen ${ }^{ \pm}$,Maria Azucena B. Lubrica ${ }^{\ddagger}$, \\ Phil S. Ocampo ${ }^{+}$, Kenneth B. Pakipac ${ }^{\S}$, Marycel T. Sajise ${ }^{\natural}$ \\ Precious M. Valentin
}

This study measured the level of awareness, understanding, acceptability, clarity and consistency by the Benquet State University's personnel of the University, College and Department's vision, goals, mission and objectives (VGMO). The study also determined the manner by which the VGMOs were disseminated. The results of the study showed that brochures are the most frequent manner of disseminated materials that display the University's VGMOs, leading to higher levels of awareness of them. The level of awareness, understanding, acceptability, and consistency of the University's VGMOs, the College's goals and objectives and the Department's program objectives were analog for both male and female personnel, but the clarity levels differed significantly. Faculty members, compared to non-faculty members, have higher levels of awareness, understanding, acceptability, clarity and consistency in their recognition of $B S U$ 's VGMOs.

Keywords: university vision, mission, goals, objectives, awareness, personnel

\section{Introduction}

An institution has an identity which serves as a guide and inspiration to its existence. Institutions are expected to live up to the expectations mandated by their respective charter. The university considered in this study is one such institution established by virtue of PD 2010 signed on January 12, 1986. The mandate of Benguet State University (BSU), as provided by its charter, states that the University shall provide graduate and undergraduate courses in the arts, sciences, humanities and professional fields in agriculture, natural sciences, technology, and other technical professional courses as the Board of Regents may determine and deem proper. It shall promote research, extension, agribusiness and advanced studies and progressive leadership in its field of specialization. The University envisions a premier state university in Asia and its missions are to develop people

\footnotetext{
*Professor, Benguet State University, Philippines.

${ }^{ \pm}$Associate Professor, Benguet State University, Philippines.

*Professor, Benguet State University, Philippines.

${ }^{+}$Assistant Professor, Benguet State University, Philippines.

${ }^{\S}$ Assistant Professor, Benguet State University, Philippines.

${ }^{\diamond}$ Associate Professor, Benguet State University, Philippines.

'Instructor, Benguet State University, Philippines.
} 
imbued with academic excellence; social conscience and productivity; and actively generate and promote environment-friendly, useful technologies to improve quality of life.

The College of Arts and Sciences at Benquet State Univeristy was created on May 8, 1984 under Administrative Order No. 17, s. 1984, geared towards the preparation of students for responsible leadership and for creative and useful membership of society. Specifically, education in the arts and sciences aims to 1) develop the ability to think critically, 2) establish the essential foundation for the development of productive and well-rounded citizens, 3) acquire the ability to investigate and analyze questions and problems intellectually and to present clearly ideas which are based on solid data and study, 4) attain a broad liberal education in the humanities, the natural and physical sciences and social sciences, and develop professional competence on a chosen field of specialization, 5) develop appreciation for human values and cultural heritage, and 6) develop ideals and acquire attributes and habits desirable for one's development as a human being.

Every institution is guided by its vision, goals, mission and objectives (VMGO). This study was conceptualized in the context that appropriate evaluation procedures and effective followup measures should be provided in any institution in order to make development programs efficient, effective, relevant and responsive to the needs of their stakeholders. There are activities that are directed towards attaining the University's VMGOs. In the end, these VGMOs become the unifying factor of the different components of the educational system. Students must therefore be aware of these vision, mission, goals and objectives and must have an experience of the overall operations of the educational system to have a valid perception on the effectiveness of the institution along its areas of concern.

It is the purpose of this study to assess and highlight the personnel's level of awareness, acceptability, understanding and consistency of the Vision, Mission, Goals and Objectives of Benguet State University, the goals of the College of Arts and Sciences, and the objectives of the Mathematics-Physics-Statistics Department degree programs. The findings of this study could help the department revisit its programatic objectives in order to identify and recognize areas of improvements.

The result of this study will provide relevant information to the faculty of the College of Arts and Science at BSU which will hopefully challenge them to contribute along their fields of specialization in ways and means to maintain quality service education. Results of this study would create awareness, as well as commitment for the administrators to give their full support to the programs of the college in order to deliver its services effectively to the students and its service area.

The respondents of the study were university personnel under the College of Arts and Sciences, categorized as either teaching or non-teaching personnel. A questionnaire checklist was used to gather relevant data on the vision, mission, goals and objectives of the University, the College of Arts and Sciences, and the Mathematics-Physics-Statistics Department programs respectively. The items in the questionnaire were arranged according to the objectives of the study. 


\section{Literature Review}

1. The vision, mission, goals, objectives and core values are statements that are usually the result of several key process steps found in strategic planning. However, despite their implication, educational leaders and practitioners can sometimes have a rather skeptical outlook about them. Such outlooks may stem from the thought that statements of the VMGOs and values are too broad or deliberately too vague, therefore stakeholders cannot find any real-world meaning in them and may find them synonymous with being immeasurable (Calder 2014).

2. According to Tromp and Ruben, as stated by Calder (2014), attention to ongoing evaluation practices is indispensable with monitoring the progress of planning and gauging the results. Without thoughtful consideration in identifying the proper factors to assess and the appropriate procedures for doing so, information about institutional statements of purpose, strategic direction, and value-based decision making are of little importance.

3. Evaluation of the achievement of VMGOs, therefore, can become vague for any meaningful measure of how close or how far away an institution is from a preferred future (its vision), sense of purpose (its mission), as well as assessing institutional values' claims. Of course, the clearer and more concise these statements are, the better they can be evaluated, understood, and recognized.

4. Also, according to Tromp and Ruben, as cited by Calder (2014), institutional success is ultimately about upholding its values and realizing a vision and mission even through the most demanding times. An assessment process develops an institution's ability to meet and hopefully exceed the standards set out by VMGO's statements, all of which helps an institution look at its own bearing, progress, and possibly determine if it is indeed the finest it can be.

It is the purpose of this study to assess and highlight the acceptability, understandability, clarity, consistency and congruency of the vision, mission, goals and objectives of the University; the College of Arts and Sciences (CAS) and the Mathematics-Physics-Statistics (MPS) Department degree programs.

In as much as the MPS department is concerned, it intends to revisit its program objectives statement to assess acceptability in order to identify and recognize areas of improvements when considering refinement of such in the future.

Galangco (1997) stated that vision does not just happen. As a result of conflict and negotiation, vision is developed in a dynamic way. There is a mission statement formulating some images of the school integrating different strengths. This statement has been discussed and approved by the staff; the head frequently refers to the mission statement; the head is supported in his integrative endeavors as manifested by representations of the parents, and teachers' associations; and an open and fruitful communicative climate of the school is considered by the people. The vision provides a guiding framework for the school as a whole and does not deny the personal values of individual teachers. In September 1996, the issue of The Journal of Teaching and Teacher Education mentioned that schools show a high level of teacher-quality. Student achievement is characterized by a vision and is based on strong shared values. 
Mission is a set of very broad statements that spell out what the institution is all about and how it intends to carry out vision in its educational effort (Palma 1992). According to Palma, vision is the end product envisioned at the conclusion of the educational effort based on shared beliefs and values derived from one's philosophy. It provides a focal point of unifying elements according to which the institution staff behave or perform individually or collectively (Cawaon and Aquitania 1996). The mandate of a university/college is contained in its mission statement; it declares the purpose of its existence and its accountability (Cawaon and Aquitania 1996).

The school in this study has a powerful link with the community. Since the school has its mandated mission, goal and objectives, these should be defined in order to effectively meet the demands and needs of the community. According to Cawaon and Aquitania (1996) goals are specific targets for accomplishments which can be verified at a certain time and under specifiable conditions.

Dolipas et al. (2006) conducted research that assessed the awareness and acceptability of BSU's VGMOs among students, faculty, administrators, alumni, parents of students, and staff of the University. Results of the study revealed that the majority of the respondents agree that they are aware of the VGMOs of the University, College, Department and Programs. Also, the majority of the respondents agreed that the VGMOs are acceptable to them, and that the VGMOs of the University are consistent with those of the College, Department, and Programs. The top three ways by which the respondents are able to access information on the VGMOs were through bulletin board displays, brochures and school activities. This study has a direct bearing on the proposed study which considers the new VGMOs of the University.

\section{Vision, Mission, Goals and Objectives of the University}

The vision, mission, goals and objectives of the University refers to the approved VMGOs as per BOR Resolution No. 2494, s. 2016 dated June 22, 2016. The vision reads: A PREMIER UNIVERSITY delivering world-class education that promotes sustainable development amidst climate change. The Mission: to provide quality education to enhance food security, sustainable communities, industry innovation, climate resilience, gender equality, institutional development and partnerships. The University has 5 goals with identified specific objectives under each goal.

The goals and objectives of the University are as follows:

GOAL I. To develop proactive programs to ensure relevant quality education.

Objectives:

1. To benchmark curricular and co-curricular programs with national and international standards.

2. To develop alternative learning experiences to enhance skills that match industry needs.

3. To develop innovative and relevant curricular and co-curricular programs 
4. To enhance proactive student welfare and development programs.

GOAL II. To develop proactive programs for quality service.

Objectives:

1. To enhance relevant human resource development programs.

2. To develop effective and efficient innovative platforms for cascading information.

3. To enhance and develop employee welfare programs.

GOAL III. To enhance responsive systems and procedures for transparent institutional development.

Objectives:

1. To enhance and develop innovative financial management systems.

2. To ensure transparency in all transactions in the university.

3. To ensure inclusive and consultative decision making.

GOAL IV. To develop relevant and gender sensitive research and extension programs for institutional development, sustainable communities, climate resilience, industry innovation, and partnerships.

Objectives:

1. To develop relevant multimedia tools in disseminating technology, knowledge and information generated from RDE programs.

2. To develop relevant RDE activities that will address current problems and support cultural advocacy.

3. To partner with strategic local, regional, national and international entities.

GOAL V. To strengthen and expand public-private partnership.

Objectives:

1. Sustain and pursue functional University-relation with the alumni and other organizations both in the government and nongovernment entities.

2. To strengthen the linkage among academe, industries, LGUs and community.

\section{Goals of the College}

The school has a powerful link with the community. Since the school has its mandated vision, mission, goals and objectives, these should be defined in order to effectively meet the demands and needs of the community.

The goals of the Colleges are being revised or enhanced whenever there are new University VMGOs. Part of the strategic planning of the College is to revisit the existing goals of the College and to align it by revising or enhancing it to be consistent with the new University VMGOs. The goals of the College refer to the 
2016 approved CAS goals by the CAS Academic Council. The goals are as follows: a) Promote dynamic teaching and learning engagements, research and extension activities towards climate change adaptation and resilience for sustainable development; b) Produce globally-competent and gender sensitive graduates imbued with value systems in the preservation and respect of cultural and environmental heritage; c) Establish collaborative research and disseminate scholarly outputs through relevant platforms towards innovation and product development; and d) Design and deliver mentoring expertise, management programs and leadership in community affairs.

\section{Objectives of the Programs}

The objectives of the programs refer to the specific statements of what students will become when they finish the program. The Department of Mathematics Physics - Statistics is currently offering one undergraduate program and four graduate programs. The objectives of the different programs were revised by the Department last April 2016. The following are the programs with their corresponding objectives:

\section{Bachelor of Science in Applied Statistics}

The Bachelor of Science in Applied Statistics graduates are expected to:

1. Apply concepts in statistics from research design stage to data analysis and interpretation of results and provide needed expertise in the academe, industry and community.

2. Work with precision and accuracy in the statistical consultancy while upholding the moral and ethical standards.

3. Demonstrate student/client-centeredness, leadership, integrity, diversity, efficiency and service in the practice of profession.

4. Manifest aesthetic principles and promote cultural values.

5. Exhibit life-long learning by pursuing advanced education and/or trainings in statistics or in related fields.

\section{Master of Arts in Applied Statistics}

The Master of Arts in Applied Statistics graduates are expected to:

1. Demonstrate comprehensive and in-depth knowledge on advanced statistical concepts and methodologies.

2. Apply necessary skills in research conceptualization, data management, analysis, interpretation and communication of results to end-users.

3. Conduct, publish and extend outstanding researches while promoting the solid practice of statistics in uplifting socio-cultural, economic, environmental and technical status of the academe, industry and community.

4. Manifest aesthetic principles and promote cultural values.

5. Demonstrate student/client-centeredness, leadership, integrity, diversity, efficiency and service in the practice of profession. 


\section{Master of Arts in General Science}

Graduates of Master of Arts in General Science are expected to:

1. Demonstrate competence in advanced knowledge and skills in General Science.

2. Conduct cross disciplinary researches, extension, and production activities that will contribute scientifically, socially, aesthetically, and culturally relevant outcomes for the workplace and the community.

3. Manifest student/client-centeredness, leadership, integrity, diversity, efficiency and service in the practice of profession.

\section{Master of Arts in Mathematics}

Graduates of Master of Arts in Mathematics are expected to:

1. Apply advanced and in-depth knowledge and skills in Mathematics and extend practical and relevant Mathematics competencies to the academe, industry, and community.

2. Generate innovations that will lead to efficient solutions to existing and emerging problems.

3. Manifest aesthetic principles and promote cultural values.

4. Demonstrate student/client-centeredness, leadership, integrity, diversity, efficiency and service in the practice of profession.

\section{Master of Arts in Physics}

Graduates of Master of Arts in Physics are expected to:

1. Demonstrate advanced knowledge and skills competence in Physics.

2. Conduct cross disciplinary researches, extension, and production activities that will contribute scientifically, socially, aesthetically, and culturally relevant outcomes for the workplace and the community.

3. Manifest student/client-centeredness, leadership, integrity, diversity, efficiency and service in the practice of profession.

It is the purpose of this study to assess and highlight the personnel's level of awareness, acceptability, understanding and consistency of the vision, mission, goals and objectives of Benguet State University, the goals of the College of Arts and Sciences, and the objectives of the Mathematics-Physics-Statistics Department degree programs. Also, result of this study could help the Department revisit its program objectives statement in order to identify and recognize areas of improvements.

The study was conceptualized based on the context that appropriate evaluation procedures and effective follow up measures should be provided in the institution to make programs efficient, effective, relevant and responsive to the needs of the clients. Undertakings in the University are directed towards attaining the goal and objectives of the institution. Figure 1 presents the paradigm of the study. 
Figure 1. Paradigm of Study

\begin{tabular}{|c|c|}
\hline $\begin{array}{l}\text { I. Profile of BSU } \\
\text { Personnel } \\
\text { II. Vision, Mission, Goals } \\
\text { and Objectives of the ff: } \\
\text { 1. University } \\
\text { 2. College of Arts and } \\
\text { Sciences } \\
\text { 3. Bachelor of Science in } \\
\text { Applied Statistics } \\
\text { 4. Master of Arts in } \\
\text { a. Physics } \\
\text { b. General Science } \\
\text { c. Mathematics } \\
\text { d. Applied Statistics }\end{array}$ & $\begin{array}{l}\text { 1. The level by which the VMGOs are known by BSU } \\
\text { personnel } \\
\text { 2. The level by which the meaning or implications of the } \\
\text { VMGOs are understood by the personnel } \\
\text { 3. The level by which the VMGOs are acceptable to the } \\
\text { students; } \\
\text { 4. The level by which the VMGOs of the college, department } \\
\text { programs are consistent with that of the university as perceived } \\
\text { by personnel; } \\
\text { 5. Manner of disseminating the VMGOs is most accessible } \\
\text { to the personnel } \\
\text { 6. Comparison of the level of the following when } \\
\text { respondents are group by sex and by either faculty or non- } \\
\text { faculty member } \\
\text { a. The level by which the VMGOs are known by } \\
\text { b. the level by which the meaning or implications of the } \\
\text { VMGOs are understood } \\
\text { c. The level by which the VMGOs are acceptable } \\
\text { d. The level by which the VMGOs are clear } \\
\text { d. The level by which the VMGOs of the college and } \\
\text { department programs are consistent with that of the } \\
\text { university }\end{array}$ \\
\hline
\end{tabular}

Independent Variables

Dependent Variables

The independent variables in this study are personnel profiles and the vision, mission, goals and objectives of the university; the goals of the College of Arts and Sciences (CAS); and the objectives of Mathematics-Physics-Statistics Department (MPS) programs. The dependent variables are the level of (a) knowledge of personnel of the University's VGMOs (b) understanding of the meaning or implication of the VGMOs (c) consistency of VGMOs; manner of dissemination (d) acceptability of VGMOs; and comparison of the level of awareness, understanding, clarity, acceptability and consistency when respondents were grouped according to sex and according to either faculty or non- faculty member.

\section{Objectives of the Study}

The main objective of the study was to measure the level of knowledge, understanding, acceptability and consistency of the VMGOs of the University, College of Arts and Sciences (CAS), Mathematics-Physics-Statistics Department (MPS) degree programs as perceived by selected University personnel.

Specifically, the study is to be conducted to assess the following:

1. Manner by which the VMGOs were disseminated to selected BSU personnel.

2. The level by which the VMGOs are known by selected University personnel.

3. The level by which the VMGOs are stated clearly as perceived by selected University personnel.

4. The level by which the meaning or implications of the VMGOs are understood by selected University personnel. 
5. The level by which the VMGOs are acceptable to selected University personnel.

6. The level by which The VMGOs of the college and department programs are consistent with that of the University;

Hypotheses of the Study

The following are the hypotheses of the study:

1. There is no significant difference in the manner by which the VMGOs were disseminated to selected University personnel.

2. There is an average manner by which the VMGOs were disseminated to selected University personnel

3. There is no significant difference in the level of awareness of VMGOs when personnel were grouped according to

a. Sex

b. Faculty or non-faculty

4. There is no significant difference in the level of understanding of VMGOs when personnel were grouped according to

a. Sex

b. Faculty or non-faculty

5. There is no significant difference in the level of acceptability of VMGOs when personnel were grouped according to

a. Sex

b. Faculty or non-faculty

6. There is no significant difference in the level of clarity of VMGOs perceived by University personnel were grouped according to

a. Sex

b. Faculty or non-faculty

7. There is no significant difference in the level consistency of VMGOs when University personnel were grouped according to
a. Sex
b. Faculty or non-faculty

$\underline{\text { Scope and Delimitation }}$

The respondents of the study were selected University personnel. A questionnaire checklist was used to gather relevant data on the vision, mission, goals and objectives of BSU, the CAS, and the MPS Department programs respectively. The items in the questionnaire would be arranged according to the objectives of the study. The study was conducted during the second semester of the school year 2015-2016.

\section{Methodology}

Research Design

This study uses descriptive research with a survey questionnaire to gather the 
data needed. Questionnaires were distributed to different offices in the University including the administration offices and deans' and departments' offices of the University.

\section{Respondents}

The subjects of the study were the selected faculty and non-faculty personnel of the University. There were two hundred sixty-seven (267) respondents of the study. One hundred twenty (120) of the respondents are faculty while one hundred forty seven are non-faculty members. One hundred ninety one of the respondents are female while seventy six of them were male.

\section{Instrumentation}

The instrument used in the study was patterned from the study of Cawaon and Aquitania which was drawn from the instrument constructed by Gines (1995) Chair of the Psychology Department of the Philippine Normal University. Most of the contents, however, were taken from the BSU mission and vision, the CAS goals, and the MPS Department programs' objectives.

\section{Treatment of Data}

The data gathered were analyzed using descriptive statistics, specifically frequency counts, percentages, weighted mean and rankings. The following Likert scales were used to measure the level of awareness, acceptability, understanding, clarity, and consistency:

$\begin{array}{lccc}\text { Rate } & \text { Range } & \text { Descriptive Equivalence } & \text { Symbol Used } \\ & & & \\ 1 & 1.00-1.80 & \text { Very Slightly Aware/Acceptable } & \text { VSA } \\ 2 & 1.81-2.60 & \text { Slightly Aware/Acceptable } & \text { SA } \\ 3 & 2.61-3.40 & \text { Moderately Aware/Acceptable } & \text { MoA } \\ 4 & 3.41-4.20 & \text { Very Aware/Acceptable } & \text { VA } \\ 5 & 4.21-5.00 & \text { Very Much Aware/Acceptable } & \text { VMA } \\ & & & \\ 1 & 1.00-1.80 & \text { Very Slightly Understood } & \text { VSU } \\ 2 & 1.81-2.60 & \text { Slightly Understood } & \text { SU } \\ 3 & 2.61-3.40 & \text { Moderately Understood } & \text { MoU } \\ 4 & 3.41-4.20 & \text { Much Understood } & \text { MU } \\ 5 & 4.21-5.00 & \text { Very Much Understood } & \text { VMU } \\ & & & \\ 1 & 1.00-1.80 & \text { Very Slight Clearly Stated/Consistent } & \text { VSC } \\ 2 & 1.81-2.60 & \text { Slight Clearly Stated /Consistent } & \text { SC } \\ 3 & 2.61-3.40 & \text { Moderate Clearly Stated /Consistent } & \text { MoC } \\ 4 & 3.41-4.20 & \text { Much Clearly Stated /Consistent } & \text { VC } \\ 5 & 4.21-5.00 & \text { Very Much Clearly Stated /Consistent } & \text { VMC }\end{array}$

The t-test was used to compare the level of awareness, acceptability, 
understanding, clarity, and consistency when personnel were grouped according to sex, and when respondents were grouped as to faculty or non-faculty member. The one sample t test was used to compare manner of dissemination with the average. All were tested using a 0.05 level of significance.

\section{Results and Discussion}

Table 1 presents the manner by which the vision, mission, goals and objectives are accessed by BSU personnel. The University vision, mission, goals and objectives, as well as that of the College of Arts and Sciences goals and objectives and the Mathematics-Physics-Statistics department programs' objectives, were accessed by University personnel mostly through displays followed by brochures. This is apparent since more than half of the BSU personnel within the $55-60 \%$ surveyed ranked display as the primary manner in accessing the above information. Following the display means of accessing is through brochures; the survey revealed that brochures ranked second. On the other hand, pamphlets ranked third in accessing the CAS' objectives and the department's program goals and objectives, while the BSU vision and mission and University goals and objectives were accessed through the Internet. Fourth in rank differs for each strand, for the BSU VM and BSU GO, it is accessed through pamphlets, MPS Department program goals is accessed through publications and for the CAS objectives, it is via classrooms. Fifth in rank is by way of publications that the BSU VM, BSU GO, and CAS O is accessed and it is through classroom display that the MPS department program goals were accessed. Within the 10-15\% of the respondents surveyed, they considered Internet as the sixth in rank, while 5.99\% considered the radio. On the other hand, radio and Internet placed seventh with 4$5 \%$ of the respondent surveyed. Accessing through the Internet is the last in rank with a notable $0-3 \%$ distribution of the surveyed respondent.

Table 1. Manner by Which the Vision, Mission Goals and Objectives are accessed by Personnel

\begin{tabular}{|c|c|c|c|c|c|c|c|c|c|}
\hline \multirow{3}{*}{$\begin{array}{l}\text { Manner of } \\
\text { Access }\end{array}$} & \multicolumn{8}{|c|}{ Level of Access } & \\
\hline & \multicolumn{2}{|c|}{$\begin{array}{l}\text { Vision and } \\
\text { Mission }\end{array}$} & \multicolumn{2}{|c|}{$\begin{array}{l}\text { University } \\
\text { Goals \& } \\
\text { Objectives }\end{array}$} & \multicolumn{2}{|c|}{$\begin{array}{c}\text { CAS Goals \& } \\
\text { Objectives }\end{array}$} & \multicolumn{2}{|c|}{$\begin{array}{c}\text { MPS } \\
\text { Department } \\
\text { Program } \\
\text { Objectives }\end{array}$} & \\
\hline & Percent & Rank & Percent & Rank & Percent & Rank & Percent & Rank & $\mathrm{F}$ \\
\hline Brochures & 56.93 & 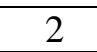 & 50 & 9 & 29.96 & 2 & 38.95 & 2 & $8.27 * *$ \\
\hline $\begin{array}{l}\text { Class } \\
\text { Orientation }\end{array}$ & 34.46 & 3 & 35.96 & 3 & 16.85 & 4 & 5.99 & 5 & $32.161 * *$ \\
\hline Internet & 13.48 & 6 & 11.99 & 6 & 8.99 & 6 & 4.49 & 7 & $4.819 * *$ \\
\hline TV & 3.00 & 8 & 3.00 & 8 & 1.50 & 8 & 0.00 & 8 & $3.003 *$ \\
\hline Radio & 5.99 & 7 & 5.99 & 7 & 4.49 & 7 & 5.99 & 6 & 0.282 \\
\hline Pamphlets & 19.48 & 4 & 19.48 & 4 & 17.98 & 3 & 11.99 & 3 & 2.388 \\
\hline Publicatio & 14.98 & 5 & 16.48 & 5 & 11.99 & 5 & 7.49 & 4 & $3.801 *$ \\
\hline Display & 59.55 & 1 & 59.55 & 1 & 60.67 & 1 & 55.06 & 1 & 0.561 \\
\hline
\end{tabular}


The result implies that despite the advent of the Internet, considered to be the quickest way of accessing information, respondents revealed that printed materials are still considered the common and frequent manner of accessing advertisements. This result is accounted for by the fact that all buildings have displays bearing the University's VMGOs, College objectives and the Department's program goals. In addition, both the College and Department distribute brochures and program prospectus of which bears the above mentioned information; and more often than not. The College and the Department do not have unified Internet portals of which this information is accessible.

The computed F-values for brochure, class orientation, internet and publication were significant at 0.05 level of significance; this implies that the manner by which the VGMOs were accessed by the personnel differ significantly. For the brochure, it ranks second as the manner by which the VGMOs were accessed by personnel, but differ in terms of number of personnel who do so. The vision and mission as a whole were accessed the most through brochures, Internet and TV. The CAS' goals and objectives as a whole were least accessed through brochures. There were more respondents who had access to the University vision, mission goals and objectives through class orientation, compared with that of the CAS' goals and objectives, and that of MPS Department program objectives. The Internet was ranked sixth by most of the respondents as manner by which the VGMOs were accessed, but there were significant differences in the number of respondents who had access through method. The University vision and mission were accessed most through the Internet, while the MPS department program objectives were least accessed through the Internet compared to the other VGMOs. This is likewise observed with access through TV where the MPS Department program objectives were never accessed through the internet. Access of the GMOs through publication was ranked fifth by the respondents, but again there was a significant difference in the number of respondents who accessed the VGMOs through this manner. The MPS program objectives were least accessed through publication materials.

Table 2 shows the comparison of the level of awareness of personnel when grouped according to sex. The level of awareness on the CAS' objectives, the female group recorded a slight level of awareness with a mean score of 2.60 , while a moderate level of awareness for the males with a 2.89 mean.

Table 2. Comparison of the Personnel's Level of Awareness of the Vision, Mission Goals and Objectives when Grouped according to Sex

\begin{tabular}{|l|c|c|c|c|c|}
\hline & \multicolumn{2}{|c|}{ Male } & \multicolumn{2}{c|}{ Female } & \multirow{2}{*}{ t value } \\
\cline { 1 - 5 } & $\begin{array}{c}\text { Wtd } \\
\text { Mean }\end{array}$ & Description & $\begin{array}{c}\text { Wtd } \\
\text { Mean }\end{array}$ & Description & t \\
\cline { 1 - 5 } 1.a. BSU Vision and Mission & 4.21 & VMA & 4.21 & VMA & $0.132^{* *}$ \\
\hline 1.b. BSU Goals and Objectives & 4.05 & MoA & 3.98 & VA & 0.082 \\
\hline $\begin{array}{l}\text { 1.c. College of Arts and } \\
\text { Sciences Objectives }\end{array}$ & 2.89 & MoA & 2.60 & SA & 0.003 \\
\hline
\end{tabular}

However, despite the differences in the level of awareness, computed t-values of 0.082 and 0.003 indicate that there is no significant difference between the two levels, which indicates that both groups exhibit analogous level of awareness on 
the BSU goals and College objectives, respectively. The computed t-value of 0.132 resulted in a highly significant difference of awareness level on the University's vision and mission between the males and females which implies that in reality, the female personnel's level of awareness differs from the males.

Table 3 presents the comparison on the personnel's level of awareness of the VMGOs according whether they were a faculty or non-faculty member. Among the University vision, mission, goals and objectives, the faculty group are very much aware while the non-faculty group are very aware as shown by the computed means of 4.57 and 4.30 for the faculty, and 3.92 and 3.76 for the nonfaculty members respectively. A moderate level of awareness the CAS' goals and objectives is revealed by faculty members while slight awareness level is shown by the non-faculty members.

Table 3. Comparison of the Personnel's Level of Awareness of the Vision, Mission Goals and Objectives when Grouped according to Faculty or Non-Faculty

\begin{tabular}{|c|c|c|c|c|c|}
\hline & \multicolumn{2}{|c|}{ Faculty } & \multicolumn{2}{|c|}{ Non-faculty } & \multirow[b]{2}{*}{$t$ value } \\
\hline & $\begin{array}{l}\text { Wtd } \\
\text { Mean }\end{array}$ & Description & $\begin{array}{l}\text { Wtd } \\
\text { Mean }\end{array}$ & Description & \\
\hline $\begin{array}{l}\text { 1.a. University Vision and } \\
\text { Mission }\end{array}$ & 4.57 & VMA & 3.92 & VA & $6.183^{* *}$ \\
\hline $\begin{array}{l}\text { 1.b. University Goals and } \\
\text { Objectives }\end{array}$ & 4.30 & VMA & 3.76 & VA & $5.043 * *$ \\
\hline $\begin{array}{l}\text { 1.c. College of Arts and Sciences } \\
\text { Objectives }\end{array}$ & 2.87 & MoA & 2.54 & SA & $1.971^{*}$ \\
\hline
\end{tabular}

Each group disclosed different levels of awareness and computed t-values of $6.183,5.043$ and 1.971 which further affirms that there are significant differences in the level of awareness between groups indeed. This shows therefore, that both groups share varying levels of awareness.

Table 4 shows the level of understanding by personnel of the University's vision and mission; and the University and the CAS' goals and objectives when grouped according to sex. For the vision and mission, the mean score is 3.94 for the male group, while the female groups mean score is 4.10 . Both scores indicated a much higher level of understanding. This much higher level of understanding is likewise accorded to both groups on their understanding of the goals and objectives, with respective mean scores of 4.00 and 4.015 . However, computed tvalues of 1.343 and .349 further affirm that both groups' level of understanding does not vary, and that they actually exhibit similar understandings of the vision, mission, goals and objectives.

Table 4. Comparison of the Personnel's Level of Understanding of the Vision, Mission Goals when Grouped according to Sex

\begin{tabular}{|c|c|c|c|c|c|}
\hline & \multicolumn{2}{|c|}{ Male } & \multicolumn{2}{|c|}{ Female } & \multirow[b]{2}{*}{ t value } \\
\hline & $\begin{array}{l}\text { Wtd } \\
\text { Mean }\end{array}$ & Description & $\begin{array}{l}\text { Wtd } \\
\text { Mean }\end{array}$ & Description & \\
\hline 1.a. University Vision and Mission & 3.95 & MU & 4.10 & $\mathrm{MU}$ & 1.343 \\
\hline 1.b. University Goals and Objectives & 4.00 & MU & 4.04 & MU & 0.349 \\
\hline $\begin{array}{l}\text { 1.c. College of Arts and Sciences } \\
\text { Objectives }\end{array}$ & 3.00 & MoU & 2.44 & SU & $3.049^{* * *}$ \\
\hline
\end{tabular}


On the other hand, the computed t-value of -3.049 bared a highly significant difference in the level of understanding between that of the male and female group under the CAS' objectives. The male group's moderate level of understanding varies significantly with the females slightly understood. This indicates that the male group has a higher level of understanding of the implication and meaning of the CAS' objectives than that of the female group.

Table 5 presents the comparison on the personnel's level of understanding of the VMGOs when personnel were grouped as either faculty or non-faculty members. Both groups have much understanding of the BSU's goals and objectives as reflected by the computed means of 4.20 and 3.89 respectively for the faculty and non-faculty members. The BSU's vision and mission are very much understood by the faculty group, but only moderately understood by the nonfaculty group. For the CAS' objectives, the faculty members slightly understood while the non-faculty group moderately understood as shown by the computed means of 2.43 and 2.74 for the two groups.

Table 5. Comparison of the Personnel's Level of Understanding of the Vision, Mission Goals and Objectives when Grouped according to Faculty or Non-Faculty

\begin{tabular}{|c|c|c|c|c|c|}
\hline & \multicolumn{2}{|c|}{ Faculty } & \multicolumn{2}{|c|}{ Non-faculty } & \multirow[b]{2}{*}{ t value } \\
\hline & $\begin{array}{l}\text { Wtd } \\
\text { Mean }\end{array}$ & Description & $\begin{array}{l}\text { Wtd } \\
\text { Mean }\end{array}$ & Description & \\
\hline 1.a. University Vision and Mission & 4.23 & VMU & 3.92 & MU & $3.004 * *$ \\
\hline $\begin{array}{l}\text { 1.b. University Goals and } \\
\text { Objectives }\end{array}$ & 4.20 & MU & 3.89 & MU & $2.879 * *$ \\
\hline $\begin{array}{l}\text { 1.c. College of Arts and Sciences } \\
\text { Objectives }\end{array}$ & 2.43 & SU & 2.74 & $\mathrm{MoU}$ & -1.846 \\
\hline
\end{tabular}

The differences in the level of understanding between the two groups were further affirmed by the computed t-values of 3.004 and 2.879 which were highly significant at a 0.05 level of significance. The difference in the levels of understanding of the CAS' objectives, though, was not significant as proven by the computed t-value of 1.846 which is not significant at a 0.05 level of significance. Hypotheses on the difference of understanding level of the BSU's vision, mission, goals and objective are therefore rejected while the hypothesis on the understanding level of the CAS' objectives is accepted.

Table 6 presents the comparison on the personnel's level of acceptability of the VMGOs according to sex. Along the vision, mission, goals and objectives the male group's respective mean scores are 3.89 and 4.13, while the female group's mean score is 3.95 and 4.13. Each mean score indicates a high level of acceptability. A moderate level of acceptability of the CAS' goals and objectives was revealed by both the male and the female groups with mean scores of 3.16 and 3.05 . 
Table 6. Comparison of the Personnel's Level of Acceptability of the Vision, Mission Goals and Objectives when Grouped according to Sex

\begin{tabular}{|c|c|c|c|c|c|}
\hline & \multicolumn{2}{|c|}{ Male } & \multicolumn{2}{|c|}{ Female } & \multirow[b]{2}{*}{$\begin{array}{c}\mathbf{t} \\
\text { value }\end{array}$} \\
\hline & $\begin{array}{c}\text { Wtd } \\
\text { Mean }\end{array}$ & Description & $\begin{array}{l}\text { Wtd } \\
\text { Mean }\end{array}$ & Description & \\
\hline 1.a. University Vision and Mission & 3.89 & VA & 4.13 & VA & 1.804 \\
\hline $\begin{array}{l}\text { 1.b. University Goals and } \\
\text { Objectives }\end{array}$ & 3.95 & VA & 4.13 & VA & 1.427 \\
\hline $\begin{array}{l}\text { 1.c. College of Arts and Sciences } \\
\text { Objectives }\end{array}$ & 3.16 & MoA & 3.05 & MoA & -0.617 \\
\hline
\end{tabular}

Despite differences in the mean score, each group disclosed a similar level of acceptability and computed t-values of $1.804,1.427$ and 0.617 , which further affirms that indeed there are no significant differences in the level of acceptability between groups. This entails therefore, that both groups share an unvarying level of acceptability.

Table 7 presents the comparison on the personnel's level of acceptability of the VMGOs according to faculty or non-faculty group. Both groups have moderate acceptance of the CAS' objectives as presented by the computed means of 3.20 and 2.99 for the two groups. For the University vision, mission, goals and objectives faculty members have a very high acceptance while the non-faculty group has a moderate acceptance as reflected by the means of 4.33 and 4.40 for the faculty group, and 3.84 and 3.81 for the non-faculty group.

Table 7. Comparison of the Personnel's Level of Acceptability of the Vision, Mission Goals and Objectives when grouped according to Faculty or Non-Faculty

\begin{tabular}{|c|c|c|c|c|c|}
\hline & \multicolumn{2}{|c|}{ Faculty } & \multicolumn{2}{|c|}{ Non-faculty } & \multirow[b]{2}{*}{$t$ value } \\
\hline & $\begin{array}{c}\text { Wtd } \\
\text { Mean }\end{array}$ & Description & $\begin{array}{c}\text { Wtd } \\
\text { Mean }\end{array}$ & Description & \\
\hline 1.a. University Vision and Mission & 4.33 & VMA & 3.84 & MA & $4.403 * *$ \\
\hline 1.b. University Goals and Objectives & 4.40 & VMA & 3.81 & MA & $5.477 * *$ \\
\hline $\begin{array}{l}\text { 1.c. College of Arts and Sciences } \\
\text { Objectives }\end{array}$ & 3.20 & MoA & 2.99 & MoA & 1.380 \\
\hline
\end{tabular}

The computed t-values of 4.403 and 5.477 were significant at 0.05 level of significance which implies that the acceptability level of the BSU's vision, mission, goals and objectives for both groups differ significantly. The hypothesis that the acceptability level on the University's vision, mission, goals and objectives is therefore rejected. For the CAS' objectives, the computed t-value of 1.38 was not significant at 0.05 level of significance which implies that both groups have same moderate acceptability level.

The comparison on the personnel's perception on the level of clarity of the VMGOs according to sex is shown in Table 8. Among the female group, they perceived a very much clear statement of the vision, mission, goals and objectives. Whereas, the CAS's objectives perceived clarity is on the moderate level. A very clear university vision, mission, goals and objective as well as CAS' goals and objectives were observed for the male group. 
Table 8. Comparison of the Personnel's Level of Clarity of the Vision, Mission Goals and Objectives when Grouped according to Sex

\begin{tabular}{|l|c|c|c|c|c|}
\hline & \multicolumn{2}{|c|}{ Male } & \multicolumn{2}{c|}{ Female } & \multirow{2}{*}{ t value } \\
\hline & $\begin{array}{c}\text { Wtd } \\
\text { Mean }\end{array}$ & Description & $\begin{array}{c}\text { Wtd } \\
\text { Mean }\end{array}$ & Description & V \\
\cline { 1 - 5 } 1.a. University Vision and Mission & 3.84 & VC & 4.27 & VMC & $3.513^{* *}$ \\
\hline $\begin{array}{l}\text { 1.b.University Goals and } \\
\text { Objectives }\end{array}$ & 4.00 & VC & 4.25 & VMC & $2.249^{*}$ \\
\hline $\begin{array}{l}\text { 1.c. College of Arts and Sciences } \\
\text { Objectives }\end{array}$ & 3.63 & VC & 3.26 & MoC & $-2.042^{*}$ \\
\hline
\end{tabular}

The differences in the mean scores of both groups under each statement did signify significant variations in the perceived level of clarity as validated by the computed t-values of 3.513, 2.249 and -2.042 . The result then indicated a varied perception of clarity between the males and females. The hypothesis that there are no significant differences in the level of clarity of the VMGOs is therefore rejected. This means that female considered the VMGOs to have been stated very clearly, but the males do not fully perceive that way as the females do.

Table 9 presents the comparison on the personnel's level of acceptability of the VMGOs when respondents were grouped as either faculty of non-faculty members. As implied by the computed means of $4.30,4.40$ and 3.77 , faculty members find the University vision, mission, goals and objectives very much clearly stated and the CAS' objectives as very clearly stated. The non-faculty members have a different level of clarity as reflected by the computed means of 4.03, 4.00 and 3.04. The non-faculty perceived the University VMGOs stated very clearly, while the CAS' objectives were stated moderately clearly.

Table 9. Comparison of the Personnel's Perception on the Level of Clarity of the Vision, Mission Goals and Objectives Grouped according to Faculty or NonFaculty

\begin{tabular}{|c|c|c|c|c|c|}
\hline & \multicolumn{2}{|c|}{ Faculty } & \multicolumn{2}{|c|}{$\begin{array}{l}\text { Non-faculty } \\
\end{array}$} & \multirow[b]{2}{*}{ t value } \\
\hline & $\begin{array}{l}\text { Wtd } \\
\text { Mean }\end{array}$ & Description & $\begin{array}{l}\text { Wtd } \\
\text { Mean }\end{array}$ & Description & \\
\hline $\begin{array}{l}\text { 1.a. University Vision and } \\
\text { Mission }\end{array}$ & 4.30 & VMC & 4.03 & VC & $2.427 *$ \\
\hline $\begin{array}{l}\text { 1.b. University Goals and } \\
\text { Objectives }\end{array}$ & 4.40 & VMC & 4.00 & VC & $4.026^{* *}$ \\
\hline $\begin{array}{l}\text { 1.c. College of Arts and } \\
\text { Sciences Objectives }\end{array}$ & 3.77 & VC & 3.04 & $\mathrm{MoC}$ & $4.552^{* *}$ \\
\hline
\end{tabular}

The computed t-values of 2.427, 4.026 and 4.552 which were all significant at 0.05 level of significance which implies that the difference in the perceived level of clarity differs significantly between the two groups; this hypothesis is therefore rejected. The clarity level of the VMGOs differs significantly as perceived by the faculty and non-faculty group.

Displayed in Table 10 is the comparison on the personnel's perception on the level of consistency of the VMGOs according to sex. With the mean scores of 3.68 and 3.75, the perceived level of consistency of the College's objectives with that of the University's VMGOs is very consistent. Similarly, with the mean scores of 
3.63 and 3.75, both sexes reflected a very consistent perceived consistency of the MPS program objectives with that of the CAS' goals and the University's VMGOs.

Table 10. Comparison of the Personnel's Level of Consistency of the Vision, Mission Goals and Objectives when Grouped according to Sex

\begin{tabular}{|c|c|c|c|c|c|}
\hline & \multicolumn{2}{|c|}{ Male } & \multicolumn{2}{|c|}{ Female } & \multirow[b]{2}{*}{$\begin{array}{c}\mathbf{t} \\
\text { value }\end{array}$} \\
\hline & $\begin{array}{l}\text { Wtd } \\
\text { Mean }\end{array}$ & Description & $\begin{array}{c}\text { Wtd } \\
\text { Mean }\end{array}$ & Description & \\
\hline $\begin{array}{l}\text { The College of Arts and Sciences } \\
\text { Objectives }\end{array}$ & 3.68 & VC & 3.75 & VC & 0.480 \\
\hline $\begin{array}{l}\text { The department of Math-Statistics } \\
\text { and Physics Degree Program } \\
\text { Objectives }\end{array}$ & 3.63 & VC & 3.75 & VC & 0.869 \\
\hline
\end{tabular}

Despite differences in the mean scores, each group disclosed alike level of perceived consistency of the CAS' goals and MPS' program objectives. The resulting t-values of 0.480 and 0.869 further affirm that indeed there are no significant differences in the perceived level of consistency between the males and the females. This entails therefore, that both groups' shares conforming perceived level of consistency. Moreover, result points out that the respondents considered and agreed to the idea that stated CAS' goals and MPS' program objectives followed a cascading protocol.

Table 11 presents the comparison on the personnel's perception on the level of consistency of the VMGOs according to faculty and non-faculty. Both groups showed same level of consistency as shown by the computed means all showing a very consistent CAS' objectives with the MPS' program objectives.

Table 11. Comparison of the Personnel's Perception on the Level of Consistency of the Vision, Mission Goals and Objectives when Grouped according to Faculty or Non-Faculty

\begin{tabular}{|c|c|c|c|c|c|}
\hline & \multicolumn{2}{|c|}{ Faculty } & \multicolumn{2}{|c|}{ Non-faculty } & \multirow[b]{2}{*}{ t value } \\
\hline & $\begin{array}{l}\text { Wtd } \\
\text { Mean }\end{array}$ & Description & $\begin{array}{l}\text { Wtd } \\
\text { Mean }\end{array}$ & Description & \\
\hline $\begin{array}{l}\text { The College of Arts and Sciences } \\
\text { Objectives }\end{array}$ & 3.93 & $\mathrm{VC}$ & 3.56 & $\mathrm{VC}$ & $3.076 * *$ \\
\hline $\begin{array}{l}\text { The department of Math-Statistics } \\
\text { and Physics Degree Program } \\
\text { Objectives }\end{array}$ & 3.93 & $\mathrm{VC}$ & 3.54 & $\mathrm{VC}$ & $3.300^{* *}$ \\
\hline
\end{tabular}

Though the descriptive equivalence of the computed means all showed to be very consistent, the differences in the mean score of each group disclosed significant difference in the level of consistency based on the computed t-values of 3.076 and 3.300 which were significant at 0.05 level of significance. This indicates therefore, that both groups shared varying levels of perceived consistency. 


\section{Conclusion}

Based on the results of the study, the following findings are therefore concluded:

1. The widespread manner of accessing the VMGOs is through the printed media such as displays, brochures, pamphlets and publications. Accessing the BSU's VMGOs through oral dissemination, such as ads on TV, radio and the Internet, were not frequently considered in accessing the University's VMGOs. There is a significant difference in the number of respondents accessing the VGMOs through brochure, class orientation, Internet, TV and publications.

2. Male and female groups exhibited significant differences in the level of awareness on the University's vision and mission, but analogous in level of awareness on the College goals and objectives; and on the program objectives. Faculty and non-faculty members also showed significant differences in the awareness level of the University VGMOs, College goals and objectives; and the Department program objectives.

3. Both female and male respondents showed no significant difference in the understanding level of the College goals and objectives, while females showed higher levels of understanding of the University's VMGOs as well as the Department's program objectives. Faculty members also showed higher understanding levels of the University's VGMOs and College's goals and objectives.

4. Both male and female respondents have the same acceptability level of the University's VGMOs as well as that of the College's and Department's program objectives. Again, faculty members showed higher acceptability level of the University's VMGOs and College goals and objectives, but analogous level with the Department program objectives.

5. Female respondents gave a significantly higher clarity level of the University's VMGOs, College goals and objectives, as well as Department program objectives; this is likewise observed with the faculty and nonfaculty members. Faculty members find the University's VGMOs, College goals and objectives, as well as the Department degree program very much clearly stated.

6. The consistency level of the University's VGMOs, College goals and objectives, and the Department program objectives were very consistent as perceived by both female and male respondents. Faculty members on the other hand gave higher consistency levels compared to the non-faculty members. 


\section{Recommendations}

Based on the conclusions, the following are recommended:

1. The University and the College should continuously work to improve the accessibility of the awareness, understanding and acceptance of its vision, mission, goals and objectives.

2. Assessment on the awareness, understanding and acceptance of the VMGOs by the personnel should be done periodically.

3. Increase awareness, understanding and acceptance of the VMGOs thru orientation and other means should be conducted among newly-hired personnel.

4. Future research undertakings should be conducted similar to this study involving other personnel and other institutions.

\section{References}

Calder WB (2014) Achieving an institution's values, vision, and mission. College Quarterly $17(2)$.

Cawaon FC, Aquitania CD (1996) Awareness and acceptability of BSU-CN mission, goal and objectives. La Trinidad, Benguet: College of Nursing, Benguet State University.

Dolipas BB, Lubrica JV, Bawang EG, Lubrica MAB, Oryan SL, Ramoss JLS et al. (2006) An assessment of the vision, mission, goals and objectives of Benguet State University; College of Arts and Sciences; Mathematics-Physics-Statistics Department; Bachelor of Science in Information Technology. La Trinidad, Benguet: Benguet State University.

Galangco NRS (1997) OAR seminary education in the Philippines: status and implication to the order of Agustinian recollects. Unpublished Dissertation. Baguio City, Philippines: Saint Louis University.

Gines AC (1995) The PNU mission, philosophy and CAS goal as perceived by PNU faculty, staff, students and alumni. Manila, Philippines: College of Arts and Sciences, PNU.

Palma JC (1992) Curriculum development system. Manila National Book Store, Inc 
